\title{
A NEW SPECIES OF COLA (MALVACEAE) FROM WEST AFRICA
}

\author{
CAREL C.H. JONGKIND \\ Nationaal Herbarium Nederland, Wageningen University branch (Herbarium Vadense) \\ Generaal Foulkesweg 37, 6703 BL Wageningen, The Netherlands \\ e-mail: Carel.Jongkind@wur.nl
}

\section{SUMMARY}

A new Cola species from the forests of Liberia is described.

Key words: Malvaceae, Cola, Africa, taxonomy.

During a recent botanical expedition in the forests of southeast Liberia an undescribed species of Cola was found. At first sight this species did look like an Octolobus species because of the size and shape of the flowers and fruits, but, after opening a flower, the single whorl of carpels with one style identified it as a species of Cola. No clear relative of the new species could be found. In the Flora of West Tropical Africa (Keay, 1958: 321 ) it can only key out as Cola altissima; however, except for the size of the flower and the single whorl of anthers, it differs in almost all other characteristics.

Cola liberica Jongkind, spec. nov. — Fig. 1

Arbuscula usque ad $5 \mathrm{~m}$ alta, monoica. Folia matura glabra, oblanceolata, basi rotundata, apice acuminata. Flores foeminei sessiles, perianthio extra piloso, calyce 7-lobato, carpellis dense tomentosis, stigmatibus papillosis. Fructus sessiles, 5 vel 6 folliculis velutinis. - Typus: Jongkind \& Blyden 5681 (holo WAG; iso K, MO), Liberia, Cestos-Sanguin area, Cooper's Logging Concession, 7 December 2002.

Monoecious treelet c. $5 \mathrm{~m}$ high. Branchlets and petiole dense, to $2 \mathrm{~mm}$ long, pale brown pilose, most hairs star-shaped. Leaves simple, more or less whorled; petiole 1.5-10 $\mathrm{cm}$ long, pulvinate at base and apex; blade oblanceolate, $13-32 \mathrm{~cm}$ long and 3.5-8.5 $\mathrm{cm}$ wide, glabrous or nearly so when mature, with 15-24 pairs of main lateral nerves, midrib prominent above; base more or less rounded; apex acuminate. Stipules long and conspicuous, brown, papery, spreading. Inflorescence sessile, between the leaves on the branch, surrounded by large brown papery bracts, looking like the stipulae. Female flowers sessile, yellow, short appressed hairy on the outside, glabrous within; calyx tube $2 \mathrm{~cm}$ long, lobes $2.5 \mathrm{~cm}$ long with a conspicuously fringed margin; carpels densely hairy; stigma papillate; anthers in one whorl. Male flowers not known. Fruits sessile, orange-brown, densely brownish hairy, wrinkled when dry; 5 or 6 follicles subglobose, c. $2.5 \mathrm{~cm}$ in diameter, 1- or 2-seeded.

Distribution \& Habit - Forests in Liberia. 


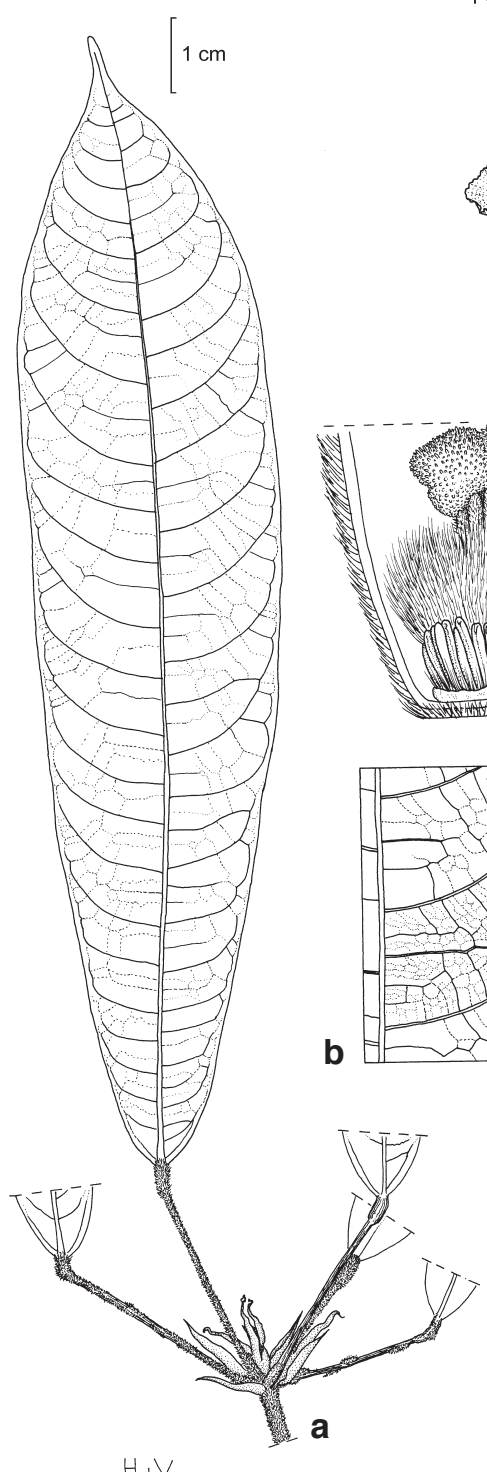

$H_{d} V$
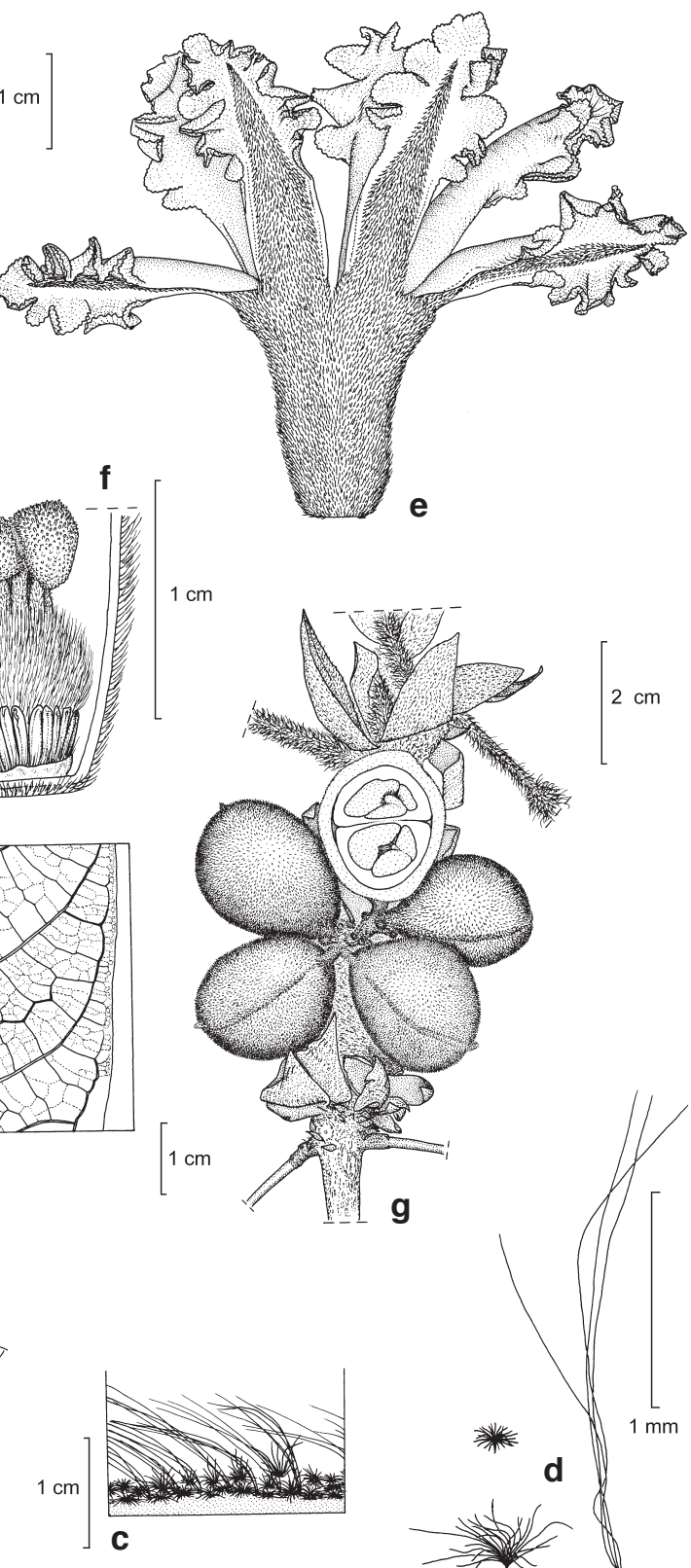

Fig. 1. Cola liberica Jongkind. a. Leaf; b. detail of the lower surface; c. detail indumentum petiole; d. individual hairs; e. flower; f. cross section flower showing carpels, style and anthers; g. mature carpels with one in cross section (a-e: Jongkind 5521; f, g: Jongkind 5681). 
Note - No other material of this species could be found in the herbaria of Kew and Wageningen, the herbaria where most collections of Liberia are stored.

Additional specimen examined:

LIBERIA: Jongkind \& Blyden 5521 (WAG), Sapo National Park, just east of Sinoe River.

\section{ACKNOWLEDGEMENT}

The expedition that found this new species in Liberia would have been impossible without the support of staff and students of the University of Liberia and of Fauna and Flora International. I am grateful for Hans de Vries for preparing the illustration.

\section{REFERENCE}

Keay, R.W.J. 1958. Flora of West Tropical Africa, second edition, part 1, 2: 321. Crown Agents for Oversea Governments and Administration, London. 